\title{
Formulation of Snack Bar from Torbangun Leaf as Food Source for Iron and Calcium
}

\author{
Formulasi Snack Bar dari Daun Torbangun sebagai Makanan Sumber Zat Besi dan Kalsium \\ Ibnu Malkan Bakhrul Ilmi ${ }^{1}$, Firlia Ayu Arini ${ }^{1}$ dan Dhebbi Novriyanti ${ }^{1}$ \\ ${ }^{1}$ Program Studi S1 Ilmu Gizi Fakultas Ilmu Kesehatan, UPN Veteran Jakarta \\ E-mail: ibnuilmi@upnvj.ac.id
}

\begin{abstract}
Indonesia has local unutilized food and it contains mineral, it is torbangun leaf. Consumption of torbangun leaf can increase level of several mineral such as iron, calcium, zink, and magnesium in breast milk. Torbangun leaf powder contains $70.77 \mathrm{mg}$ iron; $1258.29 \mathrm{mg}$ calcium; dan $97.42 \mathrm{mg}$ Phosphor. Torbangun leaf also contains lactogogum which can stimulate breast milk gland on mother by proliferating secretion cell of mamari. Therefore the quality and quantity of breast milk could increase. Torbangun leaves can be developed into emergency food items such as snack bars. The aim of this study was to develop snack bar with substitution torbangun leaves. From trial error, torbangun leaf was substitution until $10 \mathrm{~g}, 15 \mathrm{~g}$, and $20 \mathrm{~g}$. The best formula was substituted $10 \mathrm{~g}$ torbangun leaf which $9.6 \%$ protein; $10.43 \%$ fat; $66.3 \%$ carbohydrate; $1006.54 \mathrm{mg}$ calcium; and $44.76 \mathrm{mg}$ iron, with total an energy was $397.47 \mathrm{kcal} / 100 \mathrm{~g}$.
\end{abstract}

Keywords - Torbangun, Snack Bar, Iron, Calcium, Breasfeeding

\begin{abstract}
ABSTRAK
Indonesia memiliki makanan lokal yang tidak dimanfaatkan dan memiliki kandungan mineral, yaitu daun torbangun. Konsumsi daun torbangun dapat meningkatkan kadar beberapa mineral seperti zat besi, zink, dan magnesium pada Air Susu Ibu (ASI). Bubuk daun torabngun mengandung 70.77 mg zat besi; 1258.29 mg kalsium; dan $97.42 \mathrm{mg}$ fosfor. Daun torbangun juga mengandung laktogogum yang dapat menstimulasi kelenjar ASI pada ibu dengan cara memperbanyak sekresi sel mamari sehingga kualitas dan kuantitas ASI dapat meningkat. Daun torbangun dapat dikembangkan menjadi makanan darurat seperti snack bar. Tujuan dari penelitian ini adalah untuk mengembangkan snack bar dengan substistusi daun torbangun. Melalui percobaan, daun torbangun disubstitusi sampai $10 \mathrm{~g}, 15 \mathrm{~g}$, dan $20 \mathrm{~g}$. Formula terbaik adalah substitusi $10 \mathrm{~g}$ daun torbangun dengan 9,6\% protein; $10.43 \%$ lemak; $66.3 \%$ karbohidrat; $1006.54 \mathrm{mg}$ kalsium; dan $44.76 \mathrm{mg}$ zat besi, dengan total energi $397.47 \mathrm{kkal} / 100 \mathrm{~g}$.
\end{abstract}

Kata kunci-Torbangun, Snack Bar, Zat Besi, Kalsium, Menyusui

\section{INTRODUCTION}

Indonesia is prone to natural disaster. In 2018, there were earthquakes in Lombok and Palu. The result of calculation of BNPB in 2019 showed that in Indonesia there were 1,806 occurrence of disaster, 408 people were dead and missing, 855.410 victims got impact and end up as refugees. Natural disaster occur in Indonesia in 2019 were tornado 692 times, land slides 506 times, flood 502 times, forest fire 78 times, earthquake 13 times. The direct impact from natural disaster is that the victims have difficulties in accessing nutrititious, balance, various and safe food.

When the natural disaster happen, the group of baby and toddler has to be given extra 
attention, it is because in refugee camp the probability of baby and toddler death is 2-3 times as high as any other age group (WHO, 2000). Death risk will be higher on babies and toddler who were having mal nutrition. The prevalence of mal nutritious toddlers in disaster area is because the babies do not get sufficient breast milk because they are separated with their others, breast milk cannot be produced and the bad of food needs fulfillment especially for breast feeding mother (Kementerian Kesehatan RI, 2012).

Emergency food in Indonesia is dominated by rice and instant noodle product. Breast feeding mother need special care in fulfilling the nutrition to produce breast milk. The content of breast milk is maintained by body with by taking the nutrition from the mother. If the provision of food for natural disaster victim does not get special attention it will cause nutritional problem for mother and toddlers. The nutrition problem prone to happen is osteoporosis and anemia. This is because calcium and iron are needed by mother to produce breast milk, so that breast feeding mother needs more calcium and iron than usual.

Indonesia has local unutilized food and it contains mineral, it is torbangun leaf. According to Damanik et al., 2005 consumption of torbangun leaf can increase level of several mineral such as iron, calcium, zink, and magnesium in breast milk. Torbangun leaf powder contains $70,77 \mathrm{mg}$ iron, $1258,29 \mathrm{mg}$ calcium, dan 97,42 mg Phosphor (Dewi, 2011). Torbangun leaf also contains lactogogum which can stimulate breast milk gland on mother by proliferating secretion cell of mamari (Damanik et al., 2006). Therefore the quality and quantity of breast milk could increase (Damanik, 2005).

Low utilization of torbangun leaf is because torbangun leaf has bitter taste (Dewi, 2011). Therefore in this study, torbangun leaf istried to be utilized as snack bar in order to make it more appealing and can be supplement food for breast-feeding mother in refugee sites.

\section{MATERIAL AND METHODS}

Material: The material used in making snack bar consisted of main ingredient and supporting ingredient. Main ingredient was torbangun leaf. Supporting ingredient used was red bean, wheat flour, corn starch, milk powder, margarine, icing sugar, and egg yolk. Method: The design used in this study was experimental study using Complete Random Design (RAL).

Formulation: Minimum limitation of additional torbangun leaf powder was obtained from regulation of BPOM (2016) about micro nutrition fact claim of food product which is it has to contain $15 \%$ RDA to be claimed as micro nutrient source food. The result of study conducted by Dewi (2011) shows that 10 gram of torbangun leaf powder contains $125.82 \mathrm{mg}$ calcium and $7.07 \mathrm{mg}$ iron. Meanwhile the determination of maximum limit was obtained from trial and error result, the addition of 20 gram torbangun create black in color of end product, strong unpleasant smell and bitter taste. Therefore the maximum limit of terbangun powder used was 20 gram. 
Processing: Development of torbangun leaf flour: First the torbangun leaves were sorted and washed thoroughly. After that, the torbangun leaves were blanched then the torbangun leaves were dried using an oven with a temperature of $60-65^{\circ} \mathrm{C}$ for $5-7$ hours. After the dried leaves were mashed, then sift the 80 mesh.

Torbangun leaf snack bar: Butter and egg yolk were stirred to cream. After that added torbangun flour, flour, cornstarch and milk. Then add red peanut butter, honey and raisins. The dough were formed and baked with a temperature of approximately $150^{\circ} \mathrm{C}$ for $15-20$ minutes. After cooking, the bar is cooled for 30 minutes then packed.

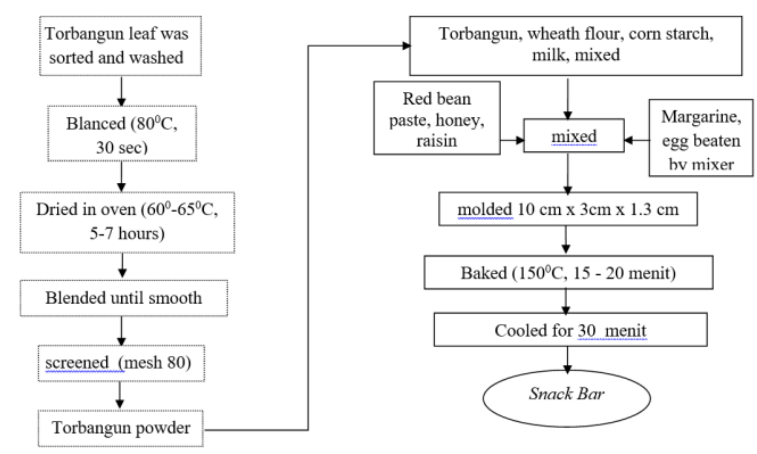

Figure 1. Torbangun snack bar making process

Organoleptic evaluation of torbangun snack bar: The developed products were evaluated for their colour, flavour, taste, texture and after taste by a panel of 40 college student from the department of Nutritional Science, Faculty of Health Science Pembangunan Nasional Veteran Jakarta University, Indonesia.

Stastistical Analysis. The sample was analized by using ANOVA, if it shows significant difference $(\alpha<0.05)$ it was continued to Duncan test. Nutritional content was analyzed by using sample independen t-test.

\section{RESULT AND DISCUSSION}

This study was conducted through several steps, those were torbangun powder making, snack bar formula determination, organoleptic test and nutritional content analysis of the formula. Torbangun powder making process consisted of, torbangun leaf washing, blanching using hot water, drying in oven, grinding, and screening.

Torbangun powder was sorted and washed. After that torbangun leaf was blanched and dried using oven at the temperature of 60$65^{\circ} \mathrm{C}$ for 5-7 hours. After being dried the leaf is ground into powder. It was screened using 80 mesh screener. The making of torbangun powder is a modification from the procedure of torbangun powder making conducted by Dewi (2011). In study conducted by Dewi (2011) drum dryer as drying method was used. In this study modification was done which is blanching and dried in oven. The product of torbangun powder had $9,84 \%$ water content, $12,7 \%$ ash, $19,5 \%$ protein, $7,76 \%$ fat, $50,2 \%$ carbohydrate, $1203,83 \mathrm{mg}$ calcium and $262,01 \mathrm{mg}$ iron.

The minimum limitation of additional torbangun leaf formula is based on the regulation of BPOM (2016) about micro nutrient claim of food product. Food product can be claimed as micro nutrient source if it contains $15 \%$ RDA and it was obtained from the 10 grams of additional torbangun powder. Meanwhile maximum limit is based on trial and 
error. The result shows that the additional torbangun powder for more than 20 gram produced black snack bar, bitter taste and intolerable unpleasant smell. Therefore the maximum limitation of additional torbangun powder was 20 grams, hence in this study torbangun powder added was 10 (F1), 15 (F2), and 20 (F3) gram.

Table 1. Formulation Torbangun Snack Bar

\begin{tabular}{cccc}
\hline Food Material & F1 $(\mathbf{g})$ & F2 $(\mathbf{g})$ & F3 $(\mathrm{g})$ \\
\hline Torbangun & 10 & 15 & 20 \\
powder & & & \\
Wheat flour & 20 & 15 & 10 \\
Red bean paste & 20 & 20 & 20 \\
Corn starch & 5 & 5 & 5 \\
Milk powder & 10 & 10 & 10 \\
Egg yolk & 10 & 10 & 10 \\
Butter & 10 & 10 & 10 \\
Honey & 20 & 20 & 20 \\
Raisin & 10 & 10 & 10 \\
Total & 115 & 115 & 115 \\
\hline
\end{tabular}

Torbangun snack bar making consisted of several steps including cream making, dry mixing dough formation, molding, baking and cooling. The first step was butter and egg yolk is beaten in order to make it into cream form. The next step was dry ingredients such as torbanngun powder, wheat flour, corn starch and milk powder were added. After that read bean paste, honey and raisin were added. The dough was mixed evenly, it was then molded. The dough was baked in oven with the temperature of $150^{\circ} \mathrm{C}$ for $15-20$ minutes. After being baked, the bar is cooled for 30 minutes and packed.
The result of hedonic quality test showed that torbangun snack bar has ligh green color, regular aroma, sweet, after taste can be felt and the texture is soft. Based on hedonic test in overall the formula chosen was formula 1 which was added with 10 grams of torbangun powder. The chosen formula was then analyzed, which were chemical analysis of torbangun snack bar.

The result of nutrition content analysis of torbangun snack bar formula 1 showed that torbangun snack bar had 397,47 kcal energy. The energy content was obtained from protein conversion, fat and carbohydrate in unit of calorie. Carbohydrate and protein have the same calorie conversion, $4 \mathrm{cal} / 1$ grams, and 1 gram fat contains 9 cal. Refer to energy need of emergency food, it has to contain $2100 \mathrm{kcal}$. Snack contributes $10-15 \%$ of total energy. One serving size of torbangun snack bar (33 grams) contained $132.5 \mathrm{kcal}$. Therefore to fulfill the energy need of emergency food, the number of snack bar in one day was 2 bars / serving. Torbangun snack bar can contribute to fulfill energy need each snacking.

The result of Independent sample t-test of ash content of torbangun snack bar was totally different from control snack bar $(\mathrm{p}<0.05)$. this phenomenon shows that the additional of 10 gram torbangun powder gave significant effect toward ash content. The high ash content shows that torbangun snack bar contains higher mineral such as calcium and iron compare to snack bar control. In addition to ash content the result of independent sample t-test showed that torbangun 
snack bar was significantly different with the protein, carbohydrate, calcium and iron content of snack bar control $(\mathrm{p}<0.05)$. This phenomenon shows that the additional of torbangun powder can increase protein, carbohydrate, calcium and iron.

The serving size of torbangun snack bar was 33 grams. Therefore calcium and iron content of every serving size was $33,51 \mathrm{mg}$ and $43,88 \mathrm{mg}$. the amount of calcium of torbangun snack bar each serving size can fulfill the need of calcium of breast feeding mother as $25.8 \%$ of RDA and iron $43,8 \%$ RDA.

Based on BPOM (2016) regulation which started that food product in solid form can be classified as micro nutrient source if it contains at least $15 \%$ of RDA of micro nutrient and classified as high in micro nutrient if it contains more than $20 \%$ of RDA of micro nutrient. Therefore snack bar with torbangun powder addition of $10 \%$ can be claimed as food product as calcium source and high in iron. Iron in vegetables is in a form of non heme with absorption level in body as $2-3.5 \%$ (8). Consumption of vitamin $\mathrm{C}$ source can increase non heme iron absorption in body. Mucthadi D (1989) stated that food material consumption which contains ascorbate acid at the same time will increase iron absorption for 3-6 times.

\section{CONCLUSION}

Torbangun snack bar (F1) had light green color, regular aroma, sweet taste, has a little bit after taste and soft texture mostly liked by panelist. Based on holistic hedonic test, the formula chosen was F1 which was 10 gram torbangun powder additional. Chemical analysis of torbangun snack bar. The result of nutrition content of torbangun snack bar shows that it contained 397,47 kcal energy , 10,9\% water content, 2,80\% ash content, 9,60\% protein, $10,43 \%$ fat content, $66,30 \%$ carbohydrate, $1006,54 \mathrm{mg}$ calcium, and 44,76 mg iron. One portion of torbangun snack bar can fulfill the need for calcium for breast feeding mother as $25,8 \%$ RDA and iron need as $43,8 \%$ RDA.

\section{ACKNOWLEDGMENTS}

Author acknowledges support from the Indonesia Endowment Fund for Education (LPDP) Ministry of Finance Republic of Indonesia

\section{REFERENCES}

Badan Nasional Penanggulangan Bencana (BNPB). 2019, Tren Kejadian Bencana 2019. https://bnpb.cloud/dibi/ access 29 June 2019.

WHO Collaborative Study Team on the Role of Breastfeeding on the Prevention of Infant Mortality . 2000. Effect of breastfeeding on infant and child mortality due to infectious diseases in less developed countries: a pooled analysis. Lancet 355 : 451-55

Kementerian Kesehatan RI. 2012. Pedoman kegiatan gizi dalam penanggulangan bencana. Jakarta: Kementerian Kesehatan RI

Damanik R. 2005. Effect of Consumption of Tourbangun (Coleus amboinicus Lour) Soup On Micronutrient Intake Of The Bataknese Lactating Women. Media Gizi \& Keluarga. 29: 68-73.

Dewi AL. 2011. Formulasi Cookies Berbasis Pati Garut (Maranta arundinaceae Linn.) 
Dengan Penambahan Tepung Torbangun (Coleus ambinicus Lour.) Sebagai Sumber Zat Gizi Mikro. Disertasi Fakultas Ekologi Manusia. Institut Pertanian Bogor. Bogor.

Damanik, Rizal, Frans Silitonga and P.H. Siagian. 2006. Effect Of Addition Of Tourbangun Leaves (Coleus amboinicus Lour) In Feed On Mice Reproduction And Milk Production. Annals of Nutrition \& Metabolism: 441.

Badan Pengawasan Obat dan Makanan. 2016. Peraturan Kepala Badan Pengawas Obat dan Makanan : Pengawasan Klaim pada Label dan Iklan Pangan Olahan. Jakarta : BPOM.

Meiri ED. 2005. Mempelajari Kandungan Mineral dan KEtersediaan Biologis $\mathrm{Fe}$ secara in Vitro Pada Sayuran Local Daerah Palangkaraya dan sekitarnya [skripsi]. Bogor : Fakultas Teknologi Pertanian, IPB.

Muchtadi D. 1989. Evaluasi Nilai Gizi Pangan. Pusat Antar UniversitasPangan dan Gizi. IPB 
